\title{
Change Management in Hospitals
}

\author{
Unggul Gaman Satria*, Muhardi Muhardi \\ Management Faculty \\ Universitas Islam Bandung \\ Bandung, Indonesia \\ *ugamansa@gmail.com, muhardi@unisba.ac.id
}

\begin{abstract}
Along with the times and in the midst of global competition, to maintain its existence, health services have experienced rapid changes and advances in terms of organization, human resources, systems, equipment technology et cetera. This will affect the existence of health facilities, including hospitals. Hospitals that are successful in adapting and changing are the ones that will survive amidst the competition. The purpose of this study is to explore the change management efforts implemented by hospital in order to maintain its existence amidst very tight competition for health services. This research was conducted at Sekarwangi Hospital, Sukabumi, Indonesia. To obtain data, researcher conducted observations, interviews and discussions. The results showed that the BLUD Sekarwangi Hospital was already made and still making changes to maintain its existence. The implementation of financial management which is more adaptable to its needs, the application of service standards following the National Hospital Accreditation Standards (SNARS), and the enhancement of hospital type service were efforts of change management in hospitals. Every policy has pros and cons, as well as hospital policies in implementing change management, which have encountered several obstacles.
\end{abstract}

Keywords—change management, hospital

\section{INTRODUCTION}

Changes is necessity that we must face, it has become sunnatullah (Allah's will) that on its time nature will change. At least in terms of time, today will not be the same as yesterday or the day to come. Change is a process of differences between before and after conditions through an effort both from oneself and from others, which involves science, equipment and the surrounding environment. For example, in our daily life, from birth to the present, the development process from babies, children, adolescents, adults and elderly. Aren't all of those changes that inevitably? [1,2,4].

Change will continue to occur in every aspects of life starting from the people then surrounding environment, as well as health services for the community. At present, there are many types and forms of health services ranging from doctor's practice clinics, health centers, hospitals, etc. Along with rapid progress of times in the midst of global competition, to maintain its existence, health services have experienced rapid changes and advances in terms of organization, human resources, systems, equipment technology and others. Hospital is one of the health service facilities. At this time many hospitals develop themselves by making many changes, such as the use of information technology, adding experts, adding infrastructure, creating cooperation networks. Hospital is a place where people get health services [5,7].

Sekarwangi Hospital has made various changes to maintain its existence in competition between hospitals. The researcher is interested to find out what changes have been made by Sekarwangi Hospital?

\section{RESEARCH METHOD}

This study uses a qualitative descriptive method where the method is limited to the sample unit. This method was chosen to help researchers explain in depth the various problems identified in this study and collect various potential problems that arise. The sample of this research is Sekarwangi Sukabumi Hospital, Indonesia. This research was carried out in August 2020 by requiring two types of data, primary data was obtained through interviews and discussions involving related leaders, while secondary data was collected from various reports, administrative studies of data sources and relevant literature.

\section{Change MANAGEMENT}

Management and change are the wo words that make up the term change management.

Management is a process of managing human resources, infrastructure, and the surrounding environment to achieve a goal with the method of planning, organizing, actuating, controlling (POAC). Meanwhile, change is a condition of difference obtained from the previous condition. The notion of change management is a process of managing human resources, infrastructure and the surrounding environment to get a different (better) condition than the previous one [1-4,6].

Change is divided into two forms, which are change for the better or change for the worse. Of course, a better change is expected. To get better change we need a good change management as well, starting from Planning, Organizing, Actuating and Controlling. Anything we will do we must plan it well, it also applies to change management. Planning starts 
from determining the goals to be achieved and then looking for the pathway or ways to achieve these goals. In the implementation of good planning, we must pay attention to everything we have (good / bad, strengths / weaknesses) as well as pay attention to the opportunities and obstacles we might face, these are known as SWOT analysis, Strength (strength), Weakness (weakness), Opportunity (opportunity), and Threat (distraction) [7,8].

After planning, the next step is to coordinate the related parts and ensure that each section works in accordance with their respective job descriptions and there is no overlapping work, which is commonly referred as Organizing. If one does not perform in accordance with the job description, it will affect the others and will have a bad impact on the organization itself.

All plans will be in vain without any actions and implementations (Actuating). Implementation of work must be adjusted to existing plans and each job descriptions.

Nothing is perfect in this world, as well as a job, for that we need supervision (controlling). Supervision is carried out to ensure that the work is in accordance with their respective rails, there is no overlap of work and responsibilities. Thus, it is to ensure that there are no forms of irregularities either intentionally or unintentionally [7].

Change management is an effort to maintain the existence of an organization and even an effort to develop itself to become more advanced and bigger. To this matter, hospitals are required to always adapt (change) to adjust with rapid demands of the times. A hospital is one of the health service facilities that provides medical, nursing, surgery and rehabilitation services, both inpatient and outpatient care [9].

A hospital is a health service organization consisting of various types of work and various types of disciplines, ranging from restaurants (nutritional installations), hospitality (inpatient), civil engineering and architecture (infrastructure), banking (finance), medicine, nursing, pharmacy and so on. These various backgrounds and scientific disciplines must become integral part of hospital's vision and mission. This makes the Hospital a unique and complex organization.

In effort to maintain their existence, several government hospitals have tried to change their financial management system with the Regional Public Service Agency (BLUD) system, so that the hospital can get both flexibility and authority to manage its finances independently. Thus it allows the hospital to gain profit which is certainly used for the advancement of the hospital itself [10,11]. With BLUD status, hospitals can invest in human resources, buildings or medical equipment. However, not all investments can be profitable, sometimes even investments can cause losses. Therefore, hospital leaders must carefully consider investment policies by applying risk management [12].

In its service, hospital has service conducts that must be obeyed in order to provide services to the community, starting from registration, doctor examination, taking medicine, laboratory action, radiology, surgery, and other services. The hospital also has accreditation standards from both within and outside the country. The National Hospital Accreditation Standard (SNARS) is a form of Accreditation Standard issued by the Hospital Accreditation Committee (KARS), while for accreditation standards for hospital accreditation standards, one of which is the Joint Commission International (JCI) [13]

At present, hospitals are divided into several types according to the level of service, availability of medical, nonmedical personnel, other personnel, the completeness of medical equipment and infrastructure. Hospital classification consists of several types, namely: class A, B, C, and class

D. Hospital classification is a description of the capabilities of services, equipment, human resources and infrastructure according to their respective class types, and is the reference level of Class D, C, B and A. In the Era of National Health Insurance, BPJS, strict adherence to the tiered referral system and zoning system was enforced.

The tiered referral system policy has caused many hospitals to review their development direction whether type $\mathrm{D}, \mathrm{C}$ or $\mathrm{B}$ while the zoning policy has more or less reduced the size of the hospital market, impacting on plans for additional capacity. The meaning of the tiered referral system itself is a system where health services must start from the lowest grade of health service facilities (puskesmas, Pratama clinic). If the puskesmas / clinic is unable to provide services, it will be referred to a higher health facility (Type $\mathrm{C}$ Hospital) and so on [14].

\section{Change Management in Hospitals}

The most basic change management in hospital is a change from the old paradigm to the new paradigm [15]:

\section{A. Paradigm Shift towards Hospital Behavior (Table 1)}

TABLE I. A PARADIGM SHIFT TOWARDS HOSPITAL BEHAVIOR

\begin{tabular}{|l|l|}
\hline \multicolumn{1}{|c|}{ Old Paradigm } & \multicolumn{1}{|c|}{ New Paradigm } \\
\hline $\begin{array}{l}\text { - Hospital is a pure social } \\
\text { organization without business } \\
\text { element }\end{array}$ & $\begin{array}{l}\text { - Hospital has considered socio- } \\
\text { business element }\end{array}$ \\
\hline - "Patient needs us"-> "arogant" & $\begin{array}{l}\text {-We need patients" -> } \\
\text { communicative, service } \\
\text { excellent }\end{array}$ \\
\hline - Bureaucracy & - Entrepreneurship \\
\hline - Sluggish, conservatives. & $\begin{array}{l}\text { Speed, motivation, pressure, } \\
\text { Aggressive }\end{array}$ \\
\hline - Poor service & - Service excellent. \\
\hline
\end{tabular}

\section{B. Paradigm Shift towards Management (Table 2)}

TABLE II. A PARADIGM SHIFT TOWARDS MANAGEMENT

\begin{tabular}{|l|l|}
\hline \multicolumn{1}{|c|}{ Old Paradigm } & \multicolumn{1}{c|}{ New Paradigm } \\
\hline - Marketing is taboo & - Marketing is needed. \\
\hline - Part time management team. & - Fulltimemanagement team \\
\hline - Solitaire. & - Network/Chain. \\
\hline - Autopilot & - Professional. Management carries \\
\hline
\end{tabular}




\begin{tabular}{|l|l|}
\hline & out its functions \\
\hline$\cdot$ Manual System & $\begin{array}{l}\text { Fully integrated } \\
-\end{array}$ \\
& HospitalManagement Information \\
& System \\
\hline
\end{tabular}

C. A Paradigm Shift towards Human Resource Management (Table 3)

TABLE III. CHANGES IN THE Human RESOURCE MANAGEMENT PARADIGM

\begin{tabular}{|l|l|}
\hline \multicolumn{1}{|c|}{ Old Paradigm } & \multicolumn{1}{c|}{ New Paradigm } \\
\hline $\begin{array}{l}\text { - Remuneration based on } \\
\text { seniority,educations, and years } \\
\text { of service }\end{array}$ & $\begin{array}{l}\text { Job performance based } \\
\text { remuneration }\end{array}$ \\
\hline - Doctors as employees. & $\begin{array}{l}\text { - Doctors: } \\
\text { Supplier/Client/Customer. }\end{array}$ \\
\hline - Doctors : Parstime employees. & $\begin{array}{l}\text { Doctors : fulltime (primary) } \\
\text { and part time }\end{array}$ \\
\hline $\begin{array}{l}\text { Recruitments: Nepotism with } \\
\text { magic letters }\end{array}$ & Recruitments: Professional \\
\hline
\end{tabular}

D. Paradigm Shift towards Organizational Structure (Table 4)

TABLE IV. A PARADIGM SHIFT TOWARDS THE ORGANIZATION

\begin{tabular}{|l|l|}
\hline \multicolumn{1}{|c|}{ Old Paradigm } & \multicolumn{1}{c|}{ New Paradigm } \\
\hline $\begin{array}{l}\text { "Fat and Deep" - Poor in } \\
\text { functions }\end{array}$ & $\begin{array}{l}\text { Lean and flat - loaded in } \\
\text { functions }\end{array}$ \\
\hline
\end{tabular}

E. Paradigm Change towards Financing (Table 5)

TABLE V. A PARADIGM SHIFT TOWARDS FINANCING

\begin{tabular}{|l|l|}
\hline \multicolumn{1}{|c|}{ Old Paradigm } & \multicolumn{2}{|c|}{ New Paradigm } \\
\hline - "Out of pocket" & $\begin{array}{l}\text { National Health Insurance } \\
\text { BPJS }\end{array}$ \\
\hline
\end{tabular}

\section{F. Paradigm Shift towards Hospital Values (Table 6)}

TABLE VI. A PARADIGM SHIFT TOWARDS HOSPITAL VALUES

\begin{tabular}{|c|c|}
\hline Old Paradigm & New Paradigm \\
\hline $\begin{array}{l}\text { - Hospitalvalues } \\
\text { unformulated }\end{array}$ & - Has values. \\
\hline $\begin{array}{l}\text { - Good coorporate } \\
\text { goverenment }(\mathrm{GCG}) \text { is not } \\
\text { implemented. }\end{array}$ & $\begin{array}{l}\text { - Implementing Good } \\
\text { coorporate goverenment, such } \\
\text { as: } \\
\text { Accountability, Responspancibility, } \\
\text { Integrity, Fairness }\end{array}$ \\
\hline
\end{tabular}

Changing (paradigm) a person's perspective on something that has been going on for years is not easy, changes in organizations and public policies are also faced with several obstacles and challenges. The acceptance of a policy is due to various reasons and various interests, be it political interests, economic or socio-cultural. This matter illustrates about things that are new and unfamiliar in changing are not necessarily expected. Internal and external factors in an organization can become obstacles or drives of changes. For example, human force which is part of the internal organization. When organization consists of people who understand the importance of change, change will run smoothly without significant obstacles, but if the organization consists of people who do not understand the importance of change, then the expected changes most likely difficult to achieve. To overcome this, a more intense program of change is required. It's works the same with external factors, such as political policies regarding National Health Insurance - Social Security Administering Bodies (BPJS). This can be a drive of change which in sync with BPJS policies. Many health service facilities take advantage of the opportunities by working with BPJS to get 'The Cake'. On the other hand, the political policy regarding JKN BPJS might become a very significant obstacle, if the hospital cannot adapt to the existing conditions [4].

\section{MAnagement of Change in SEKarwangi Hospitals}

BLUD Sekarwangi Hospital is one of the hospitals owned by the Regional Government of Sukabumi Regency with a total of 367 beds. As a government-owned hospital, of course it cannot be separated from the world of bureaucracy at this time, this is a challenge for Sekarwangi Hospital to combine the nature of bureaucracy with entrepreneurship to survive in the midst of competition between hospitals and other health services. As a government hospital, the Organizational Structure for RSUD Sekarwangi must be based on existing regulations and guidelines, it needs adjustments towards a lean and flat organizational structure that is rich in functions. The leadership factor in government hospitals has major impact whether the hospital is good or not. Hospital leaders must be adept to deal with bureaucracy world, meanwhile, a government hospital leader must also comprehend the world of medicine and entrepreneurship. It is not an easy doing to become a hospital leader.

In Sekarwangi Hospital Structure, no one has been specifically assigned to marketing (marketing), this is something that must be improved. As well as there are employees who still belief that patients need hospitals, they do not realize that it is the patients who become the source of the financial resources to run the hospital. With the patient, the wheels of hospital organization are all moving, from functional personnel, management, to parking attendants. Such paradigm makes it difficult for hospitals to progress and develop. Hospitals must continue to strive to ensure that all those involved in hospital services have the same point of view which is the hospital that needs patients, in a sense that patient is the king.

In 2009, Sekarwangi Regional Hospital changed its status of financial management into BLUD system. This is a fairly fundamental change, because with the status of a BLUD, Sekarwangi Hospital is given flexibility, discretion and authority to independently manage its budgets in terms of spending for goods and services without neglecting effective and efficient principles. The Financial Management Pattern (PPK-BLUD) allows Sekarwangi Hospital to spend on goods and services, expenditure for personnel (human resources) according to their needs, such as recruiting specialist doctors, doctors, nurses, midwives and other personnel. As well as 
infrastructure spending such as buildings, medical equipment, medicines and other support facilities.

Sekarwangi Hospital is very aware that doctors and medical specialists have vital role in the hospital, for that the hospital tries to keep doctors and medical specialists working together by providing appropriate compensation using a remuneration system where wages or salary payments are adjusted with work performance. This shows that the paradigm shift towards human resource management includes the treatment of doctors and medical specialists who are already considered as suppliers (money producers), customers / clients. The hospital's special treatment of doctors and medical specialists is due to their role as the main character in the hospital business. For example, what if a patient comes to the hospital then the doctor is not there? Can you be sure that the patient will return home, so what happened? All services at the hospital do not work, starting from pharmacy, nursing, nutrition, laboratory, radiology and so on. Vice versa, a doctor / medical specialist will attract patients to come to the hospital, thus running all the wheels of organization in the hospital. The above matters make the position of a doctor / medical specialist very special in the hospital without intending to discriminate in the treatment of other personnel.

With BLUD status, hospital must have a five- year planning document called a Strategic Plan (RENSTRA). Renstra is an outline plan to achieve the Hospital Vision. The strategic plan is then translated in detail through an annual planning document called the Business Plan and Budget (RBA) which is used as a guideline for running a hospital organization. This shows a paradigm shift towards planning management to be more focused and professional.

In 2016 BLUD Sekarwangi Hospital succeeded in implementing service standards based on the National Hospital Accreditation Standards (SNARS edition I), with the title plenary. This acquisition is an official acknowledgment of the quality of service at Sekarwangi Hospital. In 2020, Sekarwangi Hospital managed to maintain the plenary title from the Hospital Accreditation Commission (KARS). This shows the consistency of Sekarwangi Hospital in providing good service. Thus, Sekarwangi Hospital is able to extend its cooperation with BPJS. BPJS patients are the biggest customers for Sekarwangi Hospital. This marks a paradigm shifts from a hospital that was previously oriented towards direct payments "out of pocket" to financing through insurance, JKN- BPJS. Financing through insurance, BPJS has weaknesses and strengths that must be considered, such as the service rate and payment time which considered long. The advantage of BPJS is its largest market share for hospitals, and that number continues to grow every year.

In 2018 Sekarwangi Hospital has succeeded in making changes and developing services, human resources, equipment and infrastructure so that it gets an operational permit as a class B hospital. So that the people of Sukabumi Regency who need class B referral services can be served at Sekarwangi Hospital. Changes and increases in the type of hospital are followed by improvements in services, infrastructure, and human resources. Currently BLUD Sekarwangi Hospital is equipped with a variety of services including: haemodialysis, operating rooms, ICU, and other services in accordance with hospital type B standards. For medical equipment, Sekarwangi Hospital BLUD is equipped with fairly sophisticated equipment to conduct such as CT scan, haemodialysis, endoscopy, computerize photography. As for human resources, Sekarwangi Hospital has succeeded in recruiting experts such as medical specialist (specialists) and even consular doctors, and other personnel.

BPJS implements a tiered referral system in which very affect hospitals that work with BPJS. There are weaknesses and strengths of changing the type of hospital to type B related to this policy. The consequence of changing the hospital type to type B will create potential loss of customers for class type C, on the other hand it will increase the potential for type $\mathrm{B}$ customers.

\section{CONCLUSION}

Sekarwangi Hospital has made various changes to maintain its existence and try to develop to be better with changes in Financial Management, Implementation of SNARS Service Standards, and an increment to the type of Hospital B. As a government-owned hospital, Sekarwangi Hospital cannot be separated from the existing bureaucratic system. This is a challenge in itself, to synergize the world of bureaucracy with the world of entrepreneurship. Not all who are involved in hospital services have a paradigm of "Hospitals need patients". Change management is a form of effort to survive and develop which requires mutual commitment and sacrifice, it takes time to process. Not all changes go as the plans; there are still obstacles and challenges.

\section{REFERENCES}

[1] J. Winardi, "Manajemen Perubahan (The management of Change)", 2005 .

[2] E.E. Tozer, Strategic IS/IT planning, Professional ed., BetterworthHeinemann, Boston, 1996.

[3] J.F. Menda, B. Tewal, and G.M. Sendow, "Pengaruh Manajemen Perubahan dan Budaya Organisasi Terhadap kinerja pegawai negeri sipil (studi pada rsud bitung)", Jurnal EMBA, vol. 6, no. 4, pp. 2578-2587, 2018.

[4] R.R. Dewi and T. Kurniawan, "Manajemen perubahan organisasi publik: mengatasi resistensi perubahan, Bisnis \& Birokrasi", Jurnal natapraja vol. 7, no. 1, pp. 53-72, 2019.

[5] I. Purnamasari and I. Kapalawi "Analisis proses manajemen sumber daya manusia di rumah sakit stella maris makassar" Jurnal MKMI, pp. 120-124, 2013.

[6] B. Sancoko, "Pengaruh Remunerasi terhadap Kualitas Pelayanan Publik", Bisnis \& Birokrasi, Jurnal Ilmu Administrasi dan Organisasi, pp. 43-51, 2010

[7] Y. Dakhi, "Implementasi poac terhadap kegiatan Organisasi dalam mencapai tujuan tertentu", Jurnal Warta Edisi 50, 2016.

[8] A.N. Hidayanto, D.S. Hartana, and I.C. Hapsari, "Strategi manajemen perubahan untuk mendukung implementasi sistem informasi rumah sakit studi kasus: rsud RAA Soewondo pati” Journal of Information Systems, vol. 6, issue. 2, 2010. 
[9] Undang Undang No. 44/2009 Tentang Rumah Sakit, 2009.

[10] J. Rondonuwu and L. Trisnantoro, "Manajemen perubahan di lembaga pemerintah: studi kasus implementasi kebijakan pelaksanaan ppk-blud di Rumah Sakit jiwa Provinsi NTB", Jurnal Kebijakan Kesehatan Indonesia, vol. 02, no. 4, 2013.

[11] Peraturan Menteri Dalam Negeri Nomor 79 Tahun 2018 tentang Badan Layanan Umum Daerah, 2018
[12] N.K. Yunita and W.D.G.S. Darma "Strategi Investasi \& Manajemen Resiko Rumah Sakit Swasta di Bali", Jurnal Manajemen dan Bisnis, vol. 16, no. 2, 2019.

[13] Kepmenkes no 129/Menkes/SK/II/2008 Tentang Standar Pelayanan Minimal, 2008

[14] Peraturan menteri kesehatan republik indonesia nomor 340/menkes/per/III/2010 tentang klasifikasi rumah sakit, 2010

[15] A. Hendarta, Materi Kuliah Reviu Manajemen Rumah Sakit Yang Profesional. Bandung, 2020. 